\title{
A report on the marine cladoceran Evadne spinifera Müller (Crustacea, Branchiopoda) in Guanabara Bay, Rio de Janeiro, Brazil
}

\author{
Andrea Marazzo ${ }^{1}$ \\ Jean L. Valentin ${ }^{1}$
}

\begin{abstract}
This note relates the occurrence of Evadne spinifera Müller, 1867 (Crustacea, Branchiopoda) in Guanabara Bay, Rio de Janeiro State, Brazil. The samples were obtained by vertical tows with a $200 \mu \mathrm{m}$ mesh-size conical net at different times over a four day period in September, 1995. Evadne spinifera densities was always low.

KEY WORDS. Cladocera, Evadne spinifera, zooplankton, Guanabara Bay, Brazil
\end{abstract}

Cladocerans are small crustaceans that mainly inhabit freshwater, with only eight truly marine species (ONBÉ 1977). As compared with the rest of marine cladoceran species, the ecological characteristics of Evadne spinifera Müller, 1867 are unfamiliar. This is probably due to its rare occurrence and low abundance in temperate and tropical neritic waters. However, its occurrence and distribution have been described in a number of papers [e.g. GIESKES 1971 (North Atlantic Ocean and the North Sea); Della Croce \& Venugopal (1972) (Indian Ocean); LONGHURST \& SEIBERT (1972) (eastern Pacific Ocean); CHENG \& CHAO (1982) (Chinese waters); Yoo \& KIM (1984) (Yellow Sea); KIM et al. (1993) (waters adjacent to Korean Peninsula)]. According to these records, E. spinifera may be considered thermophile and stenohaline, preferring the high temperatures and salinities of warm oceanic waters.

During research work about the dynamics of planktonic communities, the occurrence of E. spinifera in Guanabara Bay, Rio de Janeiro State, Southeast Brazil $\left(22^{\circ} 41^{\prime}-22^{\circ} 56^{\prime} \mathrm{S}\right.$ and $\left.43^{\circ} 02^{\prime}-43^{\circ} 18^{\prime} \mathrm{W}\right)$ was recorded. This bay has been classified as a coastal estuary with shallow and partially mixed waters. The climate is tropical humid with a rainy season occurring during summer (December - March).

The thirteen zooplankton samples were obtained at a fixed station in Guanabara Bay, with a 30m-depth. The collections were always made at different times between 12 and 15 September, 1995. Samples were collected by vertical tows using a conical net $(0.6 \mathrm{~m}$ diameter and $2.0 \mathrm{~m}$ long) with $200 \mu \mathrm{m}$ mesh size, and they were preserved with formaldeyde $4 \%$ neutralized with sodium tetraborate.

Temperature and salinity data were also obtained. Their values had low variation during the study period. Mean values for water column temperature varied between $22.7-23.1^{\circ} \mathrm{C}$, and salinity from 32.3 to 34.4 .

1) Laboratório de Zooplâncton, Departamento de Biologia Marinha, Instituto de Biologia, Universidade Federal do Rio de Janeiro. Rio de Janeiro, 21949-900 Rio de Janeiro, Brasil. E-mail: marazzo@netfly.com.br or jlv@biologia.ufrj.br 
In the laboratory, sub-samplings were made with a Folsom plankton splitter, whenever the samples displayed a large number of individuals (MCEWEN et al. 1954). Evadne spinifera occurred only in seven samples, and this species was always the least abundant. Its highest density recorded was 0.30 ind. $\mathrm{m}^{-3}$.

The presence of E. spinifera in Guanabara Bay is an unexpected fact, on account of the estuarine feature of the ambient. This bay has been intensely investigated in previous decades for its great social and economical importance, and high degree of pollution. Thus, most of the mesozooplanktonic organisms are well known, and E. spinifera had never been recorded. This fact suggests that this species does not comprise part of the local zooplanktonic community.

Evadne spinifera is a marine cladoceran species which occurs with relative abundance on Brazilian coast (e.g. ROCHA 1982; RESGALlA \& MONTÚ 1993; BONECKER et al. 1995); thus, its presence in Guanabara Bay would be related to the inflow of coastal waters in this region caused by tidal currents.

ACKNOWLEDGEMENTS. This research is part of PRONEX project, and it was supported by the Coordenadoria de Aperfeiçoamento de Pessoal de Ensino Superior (CAPES), Conselho Nacional de Desenvolvimento Científico e Tecnológico (CNPq) and Fundação de Amparo à Pesquisa do Estado do Rio de Janeiro (FAPERJ).

\section{REFERENCES}

Bonecker, A.C.T.; S.L.C. BoneCKer; C.R. Nogueira \& L.A.S. Kraus. 1995. Studies on zooplankton and ichthyoplankton in the estuarine system of Ilha Grande Bay (RJ - Brazil). Arq. Biol. Tecnol., Curitiba, 38 (2): 593-604.

Cheng, C. \& W.C. ChaO. 1982. Studies on the marine Cladocera of China II. Distribution. Acta Oceanol. Sinica 4: 731-742.

Della Croce, N. \& P. Venugopal. 1972. Distribution of marine cladocerans in the Indian Ocean. Mar. Biol. 15: 132-138.

GIESKES, W.W.C. 1971. Ecology of the Cladocera of the North Atlantic and the North Sea, 1960-1967. Neth. Jour. Sea Res. 5 (3): 342-376.

KıM, S.W.; T. ONBÉ \& K.I. Yoo. 1993. Distribution of the marine cladoceran Evadne spinifera in waters adjacent to Korean Peninsula. Jour. Oceanol. Soc. Korea 28 (1): 47-51.

Longhurst, A.R. \& D.L.R. Selbert. 1972. Oceanic distribution of Evadne in the eastern Pacific. Crustaceana 22: 239-248.

McEwEN, G.F.; M.W. JoHNSON \& T.R. Folsom. 1954. A statistical analysis of the performance of the Folsom plankton sample splitter, band upon test observations. Arch. Met. Geophys. Bioklim. 7: 502-527.

ONBÉ, T. 1977. The biology of marine cladocerans in warm temperate water, p. 383-393. In: Proceedings of a Symposium on Warm Water Zooplankton. Goa, Special Publication, UNESCO and Nat. Inst. Oceanogr., 722p.

ResGalla JR., C. \& M. Montú. 1993. Cladóceros marinhos da plataforma continental do Rio Grande do Sul - Brasil. Nauplius 1: 63-79.

RochA, C.E.F. 1982. Distribution of the marine cladocerans (Crustacea, Branchiopoda) off Santos, Brazil. Bol. Zool. Univ. São Paulo 7: 155-169.

Yoo, K.I. \& S.W. KIM. 1984. On the unrecorded species of marine cladoceran, Evadne spinifera, in Korean waters. Jour. Oceanol. Soc. Korea 19: 104.

Recebido em 07.XII.1999; aceito em 22.XII.2000. 